\title{
Decision Support System of Student Study Service Program Group Distribution Applying Process Hierarchy Analitic Method: A Case Study Lppm of Musamus University
}

\author{
Izak Habel Wayangkau*, Nilfred Patawaran, and Agus Prayitno \\ Department of Informatics, Universitas Musamus, Merauke 99600, Indonesia
}

\begin{abstract}
Student study service is a community service, education and research activity that is carried out in an interdisciplinary and intra-curricular by dividing students into each group in certain location. Its group and location were determined by applications that produce alternative choices in making decisions on the distribution of student study service groups evenly through certain methods and criteria. The research applied the analytic hierarchy process method, where problems were simplified in a hierarchy including 3 components, such as goals, assessment criteria and alternative choices. The criteria were gender, department, and location potential. Applications of system builder were Visual Basic .NET, SQL Server and Crystal Report. The results were to facilitate distribution according to the criteria balanced and time of student study service efficiently. By the application, it assisted administration staff to determine student study service distribution and was able to be developed into various features and criteria.
\end{abstract}

Keywords: service distribution, analytic hierarchy process, system builder.

\section{Introduction}

Student study service (KKN) is part of the education process related to foster students holisticly, to develop, and increase the community cability by applying science, technology, and art. It is carried out by universities through planned strategy with a scientific approach directly to community as an effort to contribute to progress socio-economic. The name change of student study service became student study service community community- cummunity empowerment learning (KKN - PPM) took place in 2006 with the purpose to empower the community to manage and implement the surrounding environment to be more value for trading as well as a form of integration of mission implementation in building the character and personality of students. It enabled students became innovative and responsible so that the students as elements of higher education as well as the younger generation who are equipped with intellectual, have the responsibility as agents of change.

KKN organized by the Institute for Research and Community Service (LPPM) of Musamus University is a real step for students to devote themselves and to strive for betterment of society towards a better contribution of students as agents of change. Previously, for KKN distribution, LPPM still applied subjective group sharing techniques which caused several problems such as location mismatches between village potential and student profiles according to students' department that was needed and comparison male and female students in each group are less evenly distributed. Thus, a decision support system is needed to assist LPPM to decide on group distribution objectively in accordance with the applicable criteria. One of decision support system methods.

Dr. Thomas L developed a decision-making method known as AHP. He was a mathematician from the University of Pittsburg in the early 1970s. AHP is designed to help the human mindset in making a decision. Mumerical score becomes a rationale in developing AHP, it is designed to arrange alternative sequences of decision making that must be adjusted to other decision making [1]. Therefore, the idea arised to undertake "Decision Support System of Student Study Service Program Group Distribution Using Process Hierarchy Analitic Method: A Case Study LPPM Musamus University" which helps LPPMs make decisions in the division of KKN groups appropriately and objectively.

With decision support system of student study service program group distribution using process AHP method, it is expected to improve the process and the quality of the results of decision making involving a collection of data and criteria to produce an ideal KKN group in which the criteria for male and female students are balanced and there are various branches of knowledge in it.

\footnotetext{
* Corresponding author : izak@unmus.ac.id
} 


\section{Material and Methods}

\subsection{Related Studies}

1. "Technique for Order Preference by Similarity to Ideal Solution" For Student Distribution of KKN (Case Study at LPPM of Ganesha Education University)". By applying this system, LPPM is able to be selective in the distribution of $\mathrm{KKN}$ students based on criteria so that it is in accordance with the location of KKN [2].

2. "Decision Support System to Determine the Best Graduate Students in Higher Education (Case Study of STMIK Atma Luhur Pangkalpinang)". By this system, it is believed that it facilitates decision makers in a university to decide the best alternatives in the selection of outstanding students [3].

3. "Designing of Decision Support Systems for Employment Enhancing and Career Planning". By this this system, it provide assistance to solve the problem of position placement and career planning effectively and efficiently in order to facilitate decision making to select the most competent employee in a certain position [4].

4. "Development Of Recruitment Decision Support Systems Informatics Engineering - Indonesian Computer University Scientific Journal of Computer and Information Technology (KOMPUTA)". This study aimed to determine the best criteria in the implementation of prospective employee recruitment according to their demands and needs and to recruit candidates fast and precisely for each division that requires prospective employees [5].

\subsection{Definition of Term}

1. Definition of Student Study Service

Student study service is a form of community service, education and research activities carried out by students with guidance from the higher education and regional governments. It is interdisciplinary and include intracurricular which is carried out by placing students in areas that cover a number of villages at certain times. This is carried out in accordance with the functions and existence of universities as institutions that are directly involved in the intellectual life of the nation and agents of change.

2. Definisi Decision Support System

Decision Support System (DSS) is a computerbased information system that provides various alternative decisions in assisting management of handling a variety of structured or unstructured problems using data and models. It provides a decision making system to support decision makers determine the alternative results of information processing with decision-making models and solve problems that are semistructured and unstructured. DSS is designed to assist decision makers in solving problems. SPK is designed in such a way that it enables people who have no basis of computer operating capabilities. It is as well designed with an emphasis on aspects of high adaptability [6].

\section{Analytic Hierarchy Process Method}

Analytic Hierarchy Process (AHP) method was developed by Thomas L. Saaty as a decision making algorithm for multi-criteria problems as well-known as Multi Criteria Decision Making or MCDM). The problem of multicriteria in AHP is simplified in the form of a hierarchy consisting of three main components such as goal of decision making, assessment criteria and alternative choices. The pictures from the are as follows. Figure 1. presents the structure of hierarchy [8].

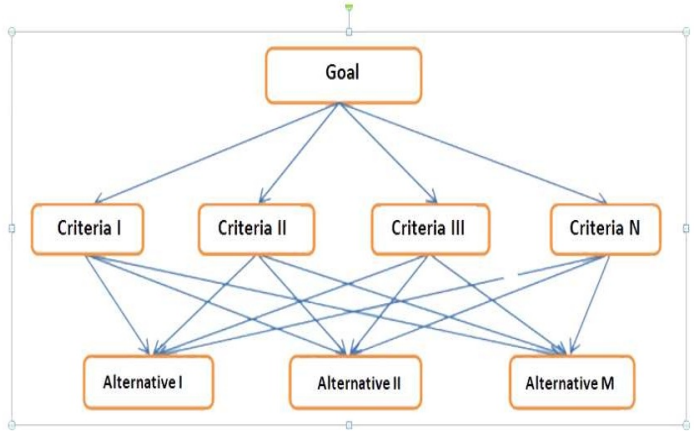

Fig. 1. Structure of Hierarchy

Settlement of problems in the AHP follows these steps [8]:

a. Define the problem and determine the solution. In this stage determine the problem that would be solved clearly, detail and easily understood. Based on the problem, determine a solution that might be suitable for the problem. Solutions for problems might be amount to more than one.

b. Create a hierarchical structure that starts with a main objective. Afterward arranging the main objective as the top level, a hierarchy level would be arranged which are the appropriate criteria to consider alternatives provided. Each criterion has a different intensity. The hierarchy is continued with subcriteria (if possible).

c. Design a paired comparison matrix that describes the relative influence of each element to the previous objectives or criteria. The matrix is simple, has a strong position for a framework of consistency, obtains other information that might be needed with all possible comparisons and is able to analyze the sensitivity of the overall priority for changing considerations. The approach to the matrix reflects the dual aspects of priorities, which are dominant. Comparison is based on judgment from decision makers by assessing the importance of an element compared to other elements. To start 
the pairwise comparison process, a criterion from the top level of the hierarchy is selected, for example $\mathrm{K}$ and then from the level below the elements to be compared are selected for example E1, E2, E3, E4, E5.

d. Define pairwise comparisons so that the total number of judgments is $n \times[(n-1) / 2]$, with $n$ is number of elements compared. The results of the comparison of each element would be a number from one to nine which presents a comparison of the importance of an element. If an element in the matrix is compared to itself, the results of the comparison are provided a value of 1 . Scale 9 is a proof to be acceptable and distinguishes intensity between elements. The results of the comparison are filled in cells that correspond to the elements compared. The scale of comparative pairings and their meanings introduced by Saaty.

Intensity of Interest

$1=$ Both elements are equally important, two elements provide the same effect

$3=$ One element is a little more important than the other elements. Judgment support a single element rather than the other

$5=$ One element is more important than the other. Judgment strongly support one element compared to the other

$7=$ One element is clearly more important than the other elements. One element that is strongly supported and dominant is seen in practice.

$9=$ One element is absolutely important than the other elements. Evidence that supports one element against another has the highest degree of affirmation that might strengthen.

$2,4,6,8=$ Values between two values of adjacent considerations, This value is given if there are two compromises between 2 choices

Reverse $=$ If in the process, $\mathrm{i}$ obtains one number compared to $\mathrm{j}$, then $\mathrm{j}$ has the opposite value compared to i.

e. Calculate eigenvalues and test their consistency.

If it is not consistent, the data retrieval is repeated.

f. Repeat steps 3,4 and 5 for all levels of the hierarchy.

g. Calculate the eigenvector of each paired comparison matrix which is the weight of each element for prioritizing elements at the lowest hierarchy level until it reaches the objective. Calculations are undertaken by summing the values of each column of the matrix, dividing each value from the column by the corresponding column to obtain the normalization of the matrix, and adding up the values of each row and dividing by the number of elements to get the average.

h. Check hierarchy consistency. The consistency ratio by looking at the consistency index is measured in AHP. The expected consistency is near perfect so as to produce a decision that is almost valid.

\section{Result and Discussion}

The result of this study was KKN group distribution applying AHP method which is displayed in a previously designed GUI.

1. Login Page

The login process is the first step that the admin undertook to be able to use the system by entering a username and password that is only known by the admin. Figure 2. presents the login page

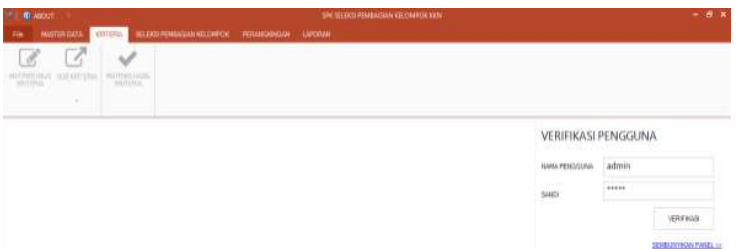

Fig. 2. Login Page

2. Participant Personal Information Page

This page was managed by adding, changing and deleting KKN participant information which was processed by the system on the next form. All the information was correct according to university database. Figure 3. presents the participant personal information page. Figure 4 . presents saved participant personal information page. Figure 5. presents final participant personal information page.

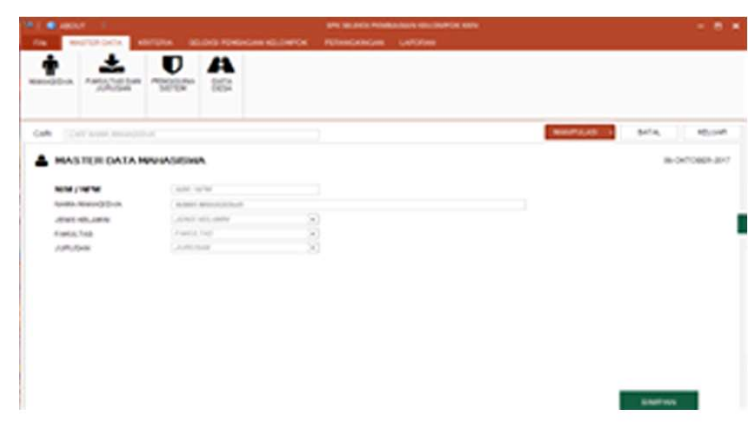

Fig. 3. Participant Personal Information Page

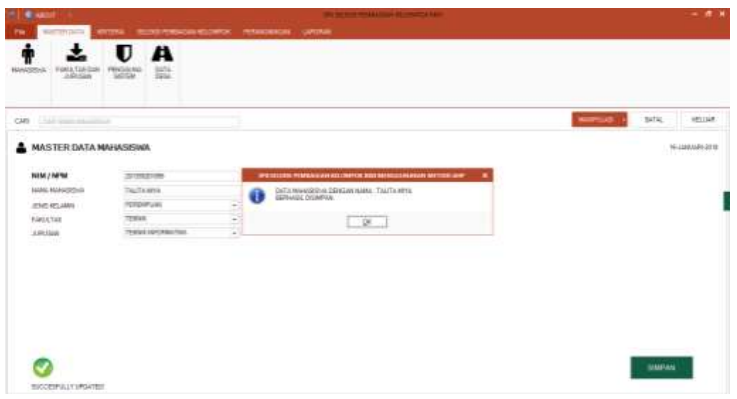

Fig. 4. Saved Participant Personal Information Page 


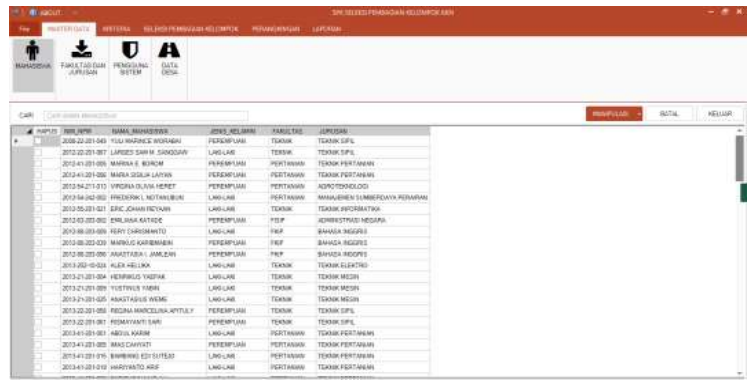

Fig. 5. Final Participant Personal Information Page

3. KKN Location Information Page

KKN location information was managed by adding, changing and deleting desan data which was processed by the next system. The village data entered was village names, village potential and priority. Figure 6. presents the KKN location information input page. Figure 7. presents the final KKN location information page.

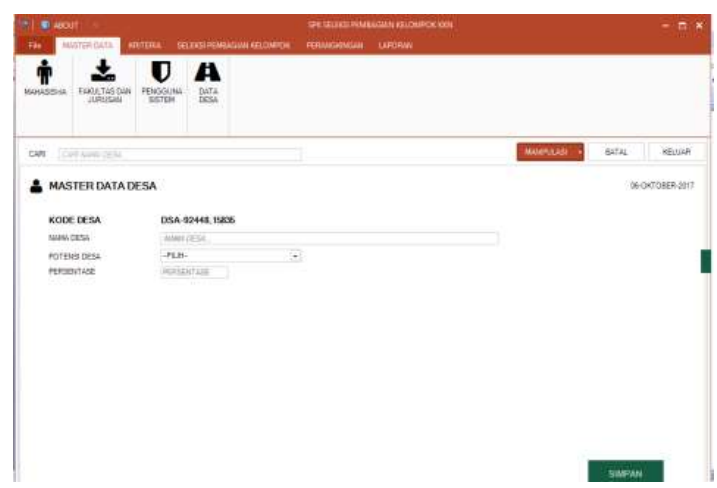

Fig. 6. KKN Location Information Input Page

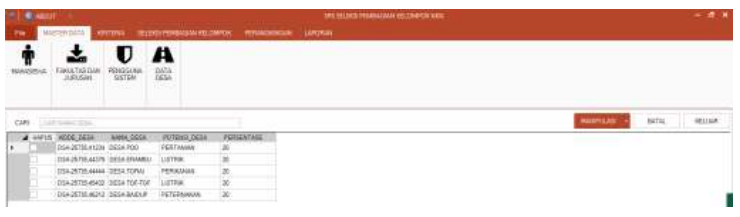

Fig. 7. Final KKN Location Information Page

4. Criteria Data Page

Criteria data matrix page was a form to determine the initial weight of each criterion in decision designing. It was processed in the AHP calculation which was used for the participant selection process. Figure 8 . presents criteria data matrix page.

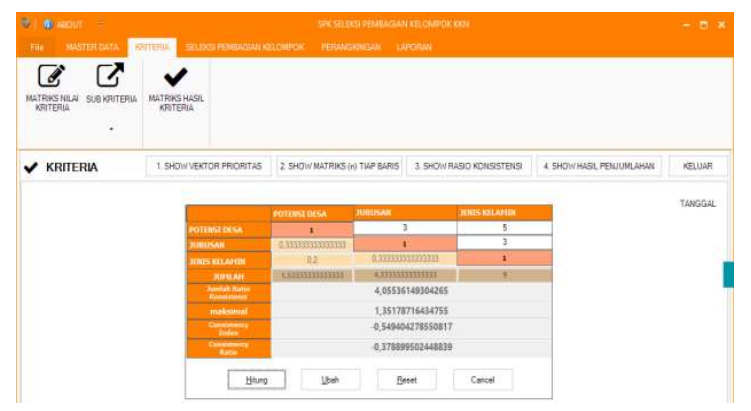

Fig. 8. Criteria Data Matrix Page

5. Participant Selection Page

This page was a form to provide the grades of participants which were registered in the data input form of participants with appropriate criteria.

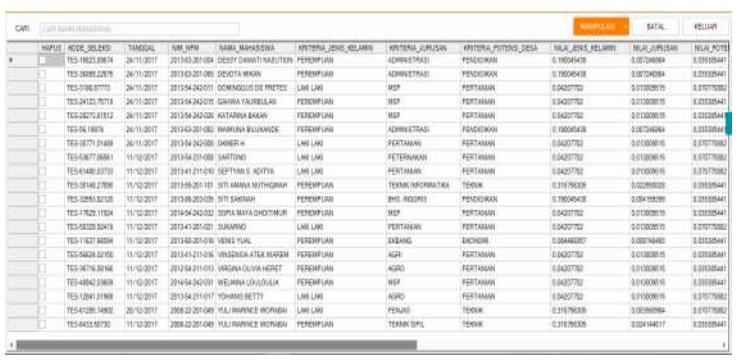

Fig. 9. Participant Selection Page

6. KKN Group Distribution

This page was a form of result of selection process.

This form provides information from participants who were distributed into KKN location. Figure 10. presents KKN group distribution page

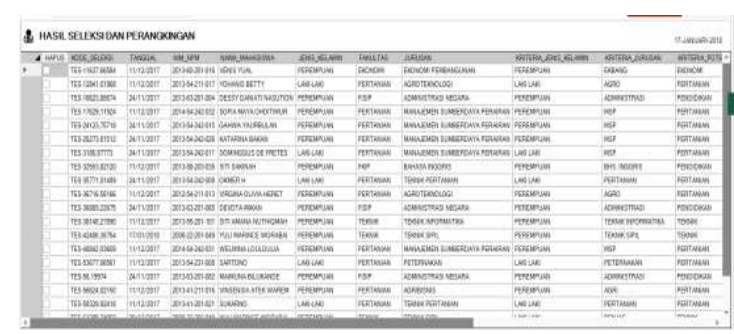

Fig. 10. KKN Group Distribution Page

7. Participant's Report Page

This page was a form providing a report display of KKN participants. The reports were printed as accountability reports to LPPM Musamus University. Figure 11. presents participant's report. Page. 


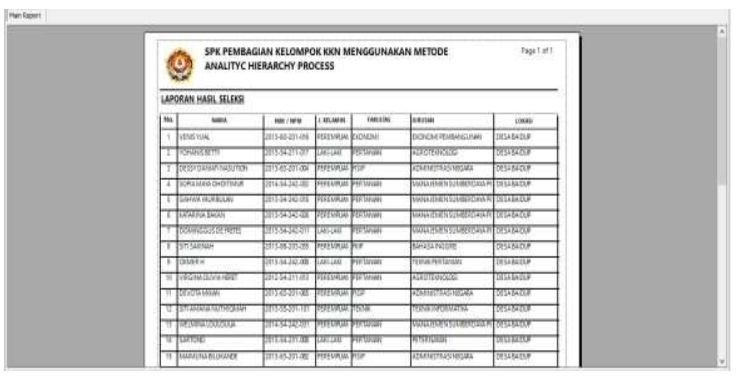

Fig. 11. Participant's Report Page

\section{Conclusion}

1. KKN Group Distribution Decision Support System was undertaken well. It was described the results of the selection of KKN participants based on gender, department and KKN location village.

2. AHP method could be applied to the DSS for KKN group distribution at Musamus University in a balanced manner according to various predetermined criteria.

\section{References}

1. Y. Sonatha and M. Azmi, "Penerapan Metode AHP dalam Menentukan Mahasiswa Berprestasi The Implementation of AHP' s Method to Determine Student 's Achievements," Poli Rekayasa, vol. 5, pp. 128-136, (2010).

2. A. Irawan and R. R, "Decision Support System for Alternative Site Selection of Kkn using Topsis," Int. J. Comput. Appl., vol. 150, no. 7, pp. 1-6, (2016).

3. H. Magdalena, "Sistem Pendukung Keputusan Untuk Menentukan Mahasiswa Lulusan Terbaik Di Perguruan Tinggi (Studi Kasus Stmik Atma Luhur Pangkalpinang)," Semin. Nas. Teknol. Inf. dan Komun. 2012, vol. 2012, no. Hilyah Magdalena, pp. 49-56, (2012).

4. A. S. Honggowibowo, Y. Indrianingsih, J. T. Informatika, S. Tinggi, T. Adisutjipto, and A. H. Process, "Untuk Peningkatan Jabatan Dan Perencanaan Karir," Tek. Inform., (2015).

5. J. Ilmiah, I. Komputa, P. Baru, D. I. Pt, and J. D. Bandung, "PEMBANGUNAN SISTEM PENDUKUNG KEPUTUSAN REKRUTMEN Teknik Informatika - Universitas Komputer Indonesia Jurnal Ilmiah Komputer dan Informatika ( KOMPUTA )," vol. 2, no. 2, (2013).

6. Desi Leha Kurniasih, "Sistem Pendukung Keputusan Pemilihan Laptop Dengan Metode Topsis," Pelita Inform. Budi Darma, vol. III, no. April, pp. 29-36, (2013).

7. K. Makkasau, "PENGGUNAAN METODE ANALYTIC HIERARCHY PROCESS (AHP) DALAM PENENTUAN PRIORITAS PROGRAM KESEHATAN (STUDI KASUS PROGRAM
PROMOSI KESEHATAN),” J@TI UNDIP J. Tek. Ind., vol. 7, no. 2, pp. 105-112, Feb. (2016).

8. T. L. Saaty, "How to Make a Decision: Advice for Scientists," European Journal of Operational Research, vol. 48, no. 48. pp. 9-26, (1990) 